\title{
THE ROLE OF MASS MEDIA IN CORRUPTION PREVENTION POLICIES AND DISPARITIES IN THE JUDGES' DECISIONS
}

\author{
Kif Aminanto, Kif Aminanto. Lecturer, Faculty of Law, University of Tadulako, Indonesia. \\ kifaminanto.untad@gmail.com
}

\begin{abstract}
This study aims to determine the role of mass media in corruption prevention policies and disparities in the judges' decisions. It use a qualitative approach with the data used are secondary data. The approach method used in this research was juridicalnormative. This method was used provided that the issues in the research are in the scope of the legislation and court decisions. Partnership between mass media and law enforcers may help develop cooperation among law enforcement institutions. The role of mass media in the prevention policy of corruption and differences in judges' decisions as originality in this study. This is because social media is increasingly evident in the reform era, where the demands for transparency and openness of mass media are growing and increasingly free, supported by developments in information technology, making it easier for people to access information. Freedom and technological support for the mass media then develop two conditions. Judging from their influence on public opinion, mass media can function as a non-penal measure for crime prevention policies.
\end{abstract}

Keywords: Mass media, Corruption, Judges Decision

Received: 07.12.2020 Accepted: 05.01.2021 Published: 04.02.2021

\section{BACKGROUND}

Social media is a medium to socialize with each other by online to interact with each other with no limitations of space and time. Such condition led to the birth of social media networks such as Facebook, Twitter, Instagram, WhatsApp, etc. Mass media has a considerable influence on the community's daily life. It gets more real in the reformation era, where demands for mass media transparency and disclosure are growing and gaining more freedom, supported by the development of information technology, thus allowing the community to access information easily. Such freedom and technological support for the mass media then developed two conditions. First, more ease of access to information for the community and guaranteed information democracy. Second, on the negative side, such freedom is not followed by responsibility, or in other words "out-of-line freedom", leading to negative impacts on the community as consumers of information. In general, mass media functions as a medium of information, education, entertainment, and social control as set forth in Article 3 paragraph 1 and paragraph 2 of Law Number: 40 of 1999 on Press: The Function of National Press is to serve as medium of information, education, entertainment, and social control, as well as an economic institution.

In its essence, mass media plays a great role in crime prevention policies and disparities. However, to the irony, despite us moving to the more modern era, the mass media still cannot be considered to have effectively taken role in the crime prevention policies and disparities. Today, the question is: has mass media, with freedom and important role to its advantage, accommodated the community's rights to information and helped law enforcement?

It is clear that further studies are needed in the context of crime prevention policy or criminal politics, in which mass media is a preventive attempt. However in reality, in some criminal cases, mainly large-scale criminal cases that draw public's attention, the effectiveness of such preventive attempt is still doubtful. One example is a corruption case that involves Nazarudin. Records show that Metro TV, a television station, held exclusive interview with Nazarudin via telephone several times while in fact, the police, even KPK, could not bring Nazarudin who allegedly fled to Singapore.

In terms of its influence to the public's opinion, mass media could serve as a non-penal attempt for crime prevention policy the way nonpenal attempt does and could tend to be preventive, for which the mass media should take positive role in news reporting (Reksodipuro, 2010). The process of reporting corruption cases is often done by mass media as an attempt to dismantle the mystery through continuous reporting, which then establishes the community's picture on the case (Soekanto and Mamudji, 1986). This very picture is then still going over debates and a question emerges: Is that a 
proper picture of the case? Is the reporting process helping or disrupting the criminal justice process instead?

\section{RESEARCH METHOD}

The approach method used in this research was juridical normative. The juridical-normative approach is an approach that uses the legislation and is conducted by researching literature materials or secondary data only. This method was used provided that the issues in the research are in the scope of the legislation and court decisions. Normative legal research is also called research on the rule of law itself (legislation, jurisprudence, customary law, other written laws, and principles of law) (Manan, 1999).

This research also used case approach, which is conducted by studying cases related to the issues, which had become the court's decision with permanent legal force. Wighyosoebroto (2002), divided legal research into doctrinal research and non-doctrinal research. Doctrinal research is also called normative research (specific for research of law as a positive norm), while non-doctrinal legal research is also called empirical legal research.

\section{RESULTS AND DISCUSSION}

The more general definition of press is asserted in Article 1 paragraph (1) of Law of the Republic of Indonesia Number 40 of 1999 on Press, which reads "The press is a social institution and a means of mass communication that carries out journalistic activities including seeking, obtaining, possessing, storing, processing and delivering information in the form of writing, voice, images, sound and images, as well as data and graphics and other forms using print media, electronic media, and all types of available channels."

Speaking of mass media, it is necessary to understand the theory on press as it will be connected with the form and content of mass media. There are four theories on press popularized by Siebert, namely:

1) Theory of Authoritarian Press;

2) Theory of Free Press;

3) Theory of Social Responsibility;

4) Theory of Soviet Media;

5) Theory of Media Development;

6) Theory of Democratic Media Participants.

From the above explanation, with reference to the legislation, it can be concluded that:

a. The principles of media freedom have been formulated in Article 2 of Law of the Republic of Indonesia Number: 40 of 1999 on Press, which states: "Freedom of press is one of the manifestations of public sovereignty on the basis of principles of democracy, justice, and legal supremacy" and Article 4 paragraph (1) which states:

"Freedom of press is guaranteed as a citizen right;"

b. The principles of anti-censor are formulated in Article 4 paragraph

(2) of Law of the Republic of Indonesia Number: 40 of 1999 on Press, which states: "the national press is exempted from censor, suppression, or broadcasting ban;"

c. The principle of social responsibility is formulated in Article 6 of Law of the Republic of Indonesia Number: 40 of 1999 on Press, which states that "The national press perform their role of the following:

1) Fulfilling people's right to information;

2) Promoting the basic values of democracy, encouraging the realization of legal supremacy and Human Rights and respecting diversity;

3) Developing public opinion based on the proper, accurate, and true information;

4) Performing surveillance, criticism, correction, and suggestion to matters related to the public's interests;

5) Fighting for justice and truth."

d. The principle of ownership restriction is formulated in Article 5 item g of Law of the Republic of Indonesia Number: 32 of 2002 on Broadcasting, which states: "Broadcasting is directed to: ... prevent monopoly of ownership and support health competition in broadcasting."

e. The principle of profession protection is formulated in Article 8 of Law of the Republic of Indonesia Number: 40 of 1999 on Press, which states "In performing their duties, journalists are protected by law." and Article 10 of Law of the Republic of Indonesia Number: 40 of 1999 on Press, which states 
"Press companies provide welfare to journalists and press employees in the form of share ownership and or distribution of net profit and other forms of welfare;"

f. The principle of individual rights protection is formulated in Article 6 of Law of the Republic of Indonesia Number: 40 of 1999 on Press, which states "The national press performs their role as follows: a. fulfilling people's right to information..."

Balanced reporting in the context of crime news reporting also means proportional reporting of the kinds of crime. Mass media tends to position street crimes in the bigger portion of reporting than big crimes such as white collar crime and organized crime. Both are crimes, but they pose more danger to the community. When mass media reports the kinds of crime disproportionally or tends to be exaggerating a crime news report, people will perceive that what they get from mass media is what happens in the reality, including disparity in the Judges' decisions.

Disparities in the decisions are seen as a disturbing issue in the integrated system of criminal justice, and disparity practices are not only found in Indonesia. They are universal and can be found in many countries. Corruption eradication has been performed to the best, but when there was a fraud in the legal process, the previous investigation would become unjust and futile. Therefore, mass media has the role to make a good record on the previous investigation and analyze any indication of fraud to prevent disparities in the judge's decision.

Disparities actually have come to Indonesian judges' awareness. Although the severity of sanctions is for first-level and appeal judges to decide, yet in some cases, Supreme Court Judges correct those decisions on the grounds of disproportionate sentencing. One example is Supreme Court decision Number: 662K/Pid/1992 (JPU vs Abdullah bib Tatoto and friends) and decision Number: 1168K/Pid/2000 (JPU vs Margono Kusuma Widagdo and Sri Endah Soekardi). In these two decisions, the Supreme Court overturned the court decisions for increasing prison sentences without sufficient detail of considerations and reasons.

Another reference directly mentioning disproportional sentencing is Supreme Court (MA) decision No. 143K/Pid/1993. The panel of judges, chaired by M. Yahya Harahap, considered that basically the severity of sanctions falls to the authority of judex facti. Transfer of authority to cassation judges can happen when the criminal sentencing is not in accordance with the method of committing a crime, and is associated with the extent of the impact caused by the defendant's actions. The same goes when the sentence is not in accordance with the purpose of criminal law enforcement as an act of education, correction, prevention, and repression for the community and the perpetrators.

The efforts to strengthen the role of mass media in the crime prevention policy is not only limited to the social control over law enforcement, but also by how the mass media can have the preventive function running. However in control function, the interest of human rights involved in a criminal case, for example, should also be taken into account. Hence, mass media should put public interest for their curiosity about information as well as the interest of human rights for proportional news reporting first in order to prevent them from judging an event or assassination of the characters involved. This way, they instead can work on their preventive function, legal learning, legal awareness, legal obedience, and giving deterrent effect to the lawbreakers.

Types of mass media according to the literature are as follows: printed media, electronic media, and online media or cybermedia. With the presence of internet, types of mass media are then divided into three, namely:

1. Print medium;

2. Broadcast medium (Radio and television);

3. The internet (online media, cybermedia).

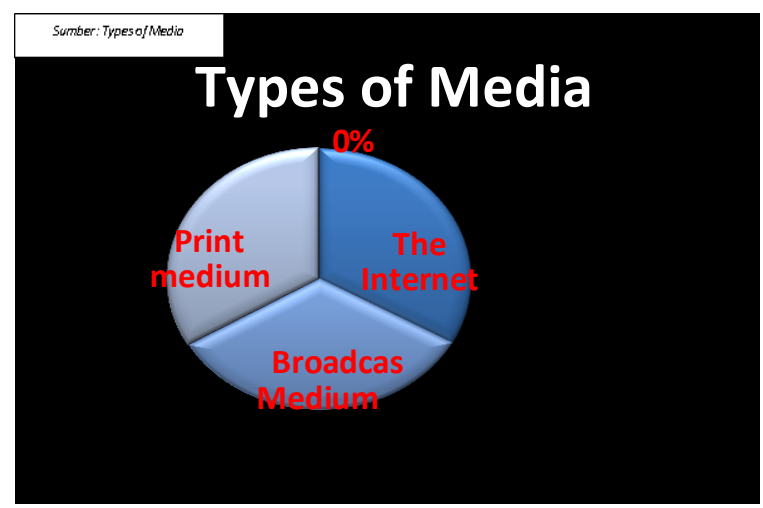

Figure 1. Types of Media 


\section{The Role of Mass Media in Minimizing Disparities in the Judges'}

\section{Decisions Particularly in Corruption Crime Cases}

The role of mass media varies widely, which includes age ranges and all information sought by the community. Mass media communication is a highly necessary for the community since they need to search and find the information. One example is information on a corruption case. It is inevitable that people will seek information on the case to know in detail and ensure that none of their relatives are involved. Given the great importance of mass media in presenting information, they have the following:

\section{Characteristics of Mass Media}

Mass media also has traits of their benchmarks. A mass media has all of the following characteristics (Assegaf, 1991):
a) Institutional;
b) One Way;
c) Widespread and simultaneous;
d) Technical or mechanical equipment in use;
e) Open.

\section{Roles of Mass Media}

Mass media has the role to ensure that it is needed in the everyday lives of the community. Without it, people will miss the news, not knowing about events occurring somewhere far away from their reach.

2) McQuail (2002), provided some key assumptions on the role or function of media among the community today:

a) Media as Industry;

b) Media as Source of Power;

c) Media as Place of Information;

d) Media as means of cultural development.

3) Effendy (1989), stated that mass communication has various functions in general, namely:

a) Information;

b) Education;

c) Influence.

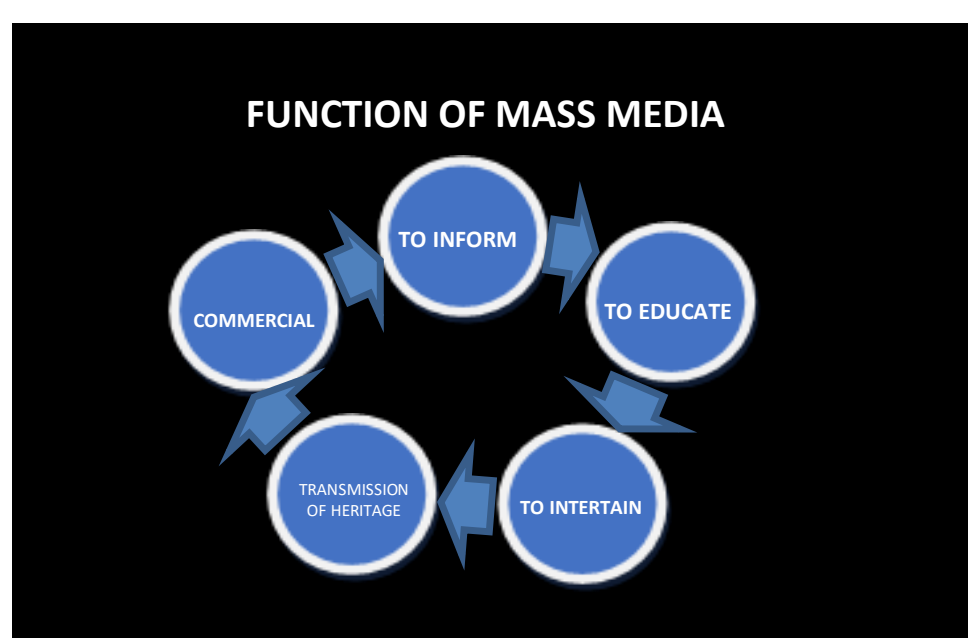

Figure 2. Function of Mass Media

The advantages of mass media are its complete and actual news that can reach the community in a short time, it is easy to store and bring, and it has affordable price. As for the disadvantages, mass media gives too little or short messages, shows less attractive pictures, bores the readers, and is only useful for literate people.

1) Tabloid has a format of newspaper but smaller (597 mm X $375 \mathrm{~mm}$ ) than standard daily newspaper size. This term is commonly associated with the publishing of non-daily regular newspaper, namely the weekly, biweekly, and so on, which focuses on "less serious" information, such as celebrity, sports, crime, etc.; 
2) Magazine according to Indonesian Dictionary is periodicals which contents include various journalistic coverage and views on actual topics that should be known to the reader. Based on its publishing schedule it can be monthly, biweekly, weekly, etc. while based on its contents, it is classified to news, women, sports, teenagers, literature, certain knowledge, and so on;

3) Bulletin is publication by an organization that brings up the development of a topic or a certain aspect and is published/issues periodically in a relatively short time (daily to monthly).

The social network has been an important aspect in business. Facebook, Messenger, Twitter, Blackberry, etc. are distinctive networks that offer different benefits to the companies. Additionally, according to Puntoadi, there are several types of social media (Syah, 2011):

1) Bookmarking: a website address that users find attractive for bookmarking sharing;

2) Content sharing: people create various media and publications through content sharing sites to share with other people. Youtube and Flickr are content sharing sites visited by most people;

3) Wiki is a site with different characteristics. It is a knowledge sharing site, and one of its branches is wikitravel, which focuses on information about more exclusive places and community concept;

4) Flickr is a site owned by Yahoo that focuses on image sharing with professional contributors from all fields of photography around the world.

5) Social network is an activity that uses features provided by certain sites to make a relationship and interact with each other. Social networking sites include LinkedIn, Facebook, and Myspace.

6) Creating opinion is social media that provides means of opinion sharing through opinion creation, allowing anyone to be a writer, journalist, and commentator at the same time.

\section{Mass Media and Hoax}

Today, truthful information or news is no longer easy to find. Mastel (2016) survey revealed that out of 1,146 respondents, $44.3 \%$ of them received hoax-containing news every day and $17.2 \%$ received more than one of such news every day. Even mainstream media, which are relied upon as trustworthy media, are sometimes contaminated by hoax spreading. Mainstream media has also become hoax-containing news/information distribution channel, with account for $1.20 \%$ (radio), $5 \%$ (print media), and $8.79 \%$ (television) (Juditha, 2018).

Not only do hoaxes spread by the mainstream media, they also spread to the community through online media. Mastel (2017) study results showed that the channels mostly used for hoax distribution are:

4) Websites at $34.90 \%$;

5) Chatting application (WhatsApp, Line, Telegram) at $62.80 \%$, and;

6) Social media (Facebook, Twitter, Instagram, and Path), the most used, at $92.40 \%$.

Meanwhile, according to the data exposed by the Ministry of Communication and Informatics, there are 800 thousand sites in Indonesia indicated as distributors of hoax and hate speech (Ibid, 2015 and Juditha, 2018).

There are three important approaches needed in anticipating distribution of hoaxes to the community, namely:

1) Institutional approach

2) Technological approach, and

3) Literacy approach.

Institutional approach is by persistently promoting anti-hoax community. From the technological approach, hoax checker application can be used by the community to crosscheck the validity of the hoaxindicated news. Literacy approach is by promoting anti-fake news movement and socialization to the community, from schools to the general public. Such actions should be improved and encouraged not only by the government, but also by all levels of community, including non-government institutions.

2. Mass Media as an Attempt of Prevention and Eradication in Corruption Crime Cases and Disparities in the Judges' Decisions

\section{Impacts of Mass Media}

A study on the impacts of media, as elaborated by Entman (1989), explained that in processing information, each human has a cognitive structure called scheme. This scheme processes what they are thinking (Etman, 1989). Inside each of human's scheme is an input on faith, values, behavior, and preferences of each individual, in line with the various existing ideas.

The impacts of a news article from the media itself, according to this study, can be seen from the interaction between the news attributes or information and people's or audience's scheme, such as faith, values, behavior, and preferences, thus the impact of the news can be seen from the interaction between 
the news's information attributes and each person's scheme. As an example, a person with strong preferences in political issues tends to be ignorant about entertainment news, and vice versa (Arrigo, 2006). This study about information process then cultivated the following four hypotheses:

1) Editorial is influencing those who identify with ideology than the moderate ones. This means that in an interaction between information attributes and their audience, the impact will be more visible to those with strong preferences of certain ideologies in their scheme. It goes the same way with the editorials that tend to be liberal; they have to drive their attitude to be more of a left towards conservative ideology.

2) Content has greater impacts on new subjects than it does on previously familiar subjects.

The impact of mass media is also explained in Social Learning Theories from Albert Bandura, who said in Chapter I that this theory identifies with the concept of reciprocal determinism. This concept explains that there is a continuous reciprocal interaction among the cognitive, behavior, and environment.

Four stages constitute the search or study, such as the involvement of the government and lawmakers, technological changes, historical events, etc. as follows:

1) All Powerful Media. This stage occurred during the transition from the $19^{\text {th }}$ century to around 1930s. Media was known to have critical power in shaping the opinion and trust to change habits and establish attitudes that were more or less similar to the controller's desires.

2) Theory of Powerful Media Put to The Test, continuation from the first stage. This stage lasted until the beginning of 1960s. In this stage, methods with developed proofs and theories were used. Researchers in this stage started to differentiate the possibly arising impacts based on social and psychological characteristics.

3) Powerful Media Rediscovered, which is related to public's opinion. In this stage, the conclusion on the minimum impacts was a particular interpretation acquired from the circulation. One of the reasons of the acquisition of minimum impacts was the birth of television in the 1950s and 1960s as new medium with more appealing force than its predecessors; a momentum that started the great influence of television on the social life.

4) Negotiated Media Influence. It works on text media, especially news, audience, and media organizations, which began in the late 1970s and brought in the approach of media impacts that can be termed social constructivist. Today Negotiated Media Influence still partly applies and is quite relevant because the author thinks that the construction made by the media today can already be negotiated, which means that the audience actually never entirely believe the information and construction of events on media. Moreover, the abundant number of mass media lets the audience pick and sort information or seek information from other media as an alternative. Negotiated Media Influence is highly relevant, given that the media conglomerate has influence on the dominant information presented to the audience, making it clear that the impact of mass media today is in this stage.

\section{Mass Media and Law}

In the context of position in crime prevention policy, mass media holds preventive role in the cases of crime as it also has the role of social control. Mass media has function in the democracy life; it is even called the fourth pillar of democracy after legislative, executive, and judicial. However, mass media also needs to be controlled by the law. According to Hari Wiryawan, there are several reasons as to why the mass media has to be regulated (Wiryawan, 2007):

3) Consideration of Public Interests;

4) Consideration of Business Interests.

The importance of guarantee of the use of public frequency or other public spheres by the mass media is in line with the considerations of public interests on Human Rights guarantee for each citizen in the democratic country. In general, the legal principles of media are as follows:

1) Principle of Media Freedom;

2) Principle of Anti-Censor.

There are two types of censor: preventive censor and repressive censor. In this principle, preventive censor is avoided since it prevents information distribution, which will eventually be considered violating the rights to acquire information.

1) Principle of Social Responsibility;

2) Principle of Ownership Restrictions;

3) Principle of Protection of Profession;

4) Principle of Individual Rights Protection. 
Looking at the above legal principles of media, with reference to the legislation, it can be concluded as follows:

1) The principle of media freedom has been formulated in Article 2 of Law of the Republic of Indonesia Number: 40 of 1999 on Press, which states: "Press freedom is a form of sovereignty based on the principles of democracy, justice, and supremacy of law" and Article 4 paragraph (1) which states "Press freedom is guaranteed as citizen rights;"

2) The principle of anti-censor is formulated in Article 4 paragraph (2) of Law of the Republic of Indonesia Number: 40 of 1999 on Press, which states "National press is exempted from censor, suppression, or broadcasting ban."

3) The principle of social responsibility is formulated in Article 6 of Law of the Republic of Indonesia Number: 40 of 1999 on Press;

4) The principle of ownership restriction is formulated in Article 5 item g of Law of the Republic of Indonesia

Number: 32 of 2002 on Broadcasting, which states "Broadcasting is directed to prevent monopoly of ownership and support health competition in broadcasting;"

5) The principle of profession protection is formulated in Article 8 of Law of the Republic of Indonesia Number: 40 of 1999 on Press, which states "In performing their duties, journalists are protected by law" and Article 10 of Law of the Republic of Indonesia Number: 40 of 1999 on Press, which states "Press companies provide welfare to journalists and press employees in the form of share ownership and or distribution of net profit and other forms of welfare;"

6) The principle of individual rights protection is formulated in Article 6 of Law of the Republic of Indonesia Number: 40 of 1999 on Press.

This function of national press is inseparable from the condition when the Law of the Republic of Indonesia Number: 40 of 1999 on Press was made, when Reformation Order was beginning and the campaign of press freedom began. In its relation to the function of national press, there is a quite great distinction between the function mentioned above and the function of national press written in Article 2 of Law of the Republic of Indonesia Number: 21 of 1982 on Principles of Press, which states "The national press is a means of national struggle and mass media that is active, dynamic, creative, educative, informative, and socially functions to encourage and it establishes critical and progressive thinking on all realizations of social life in Indonesia."

In line with the previous two Laws, Law of the Republic of Indonesia Number: 14 of 2008 on Public Information Disclosure also falls to the code of publication type as it supports the information freedom that is also part of press freedom. The goals of Law of the Republic of Indonesia Number: 14 of 2008 on Public Information Disclosure are:

1) Securing the citizen's right to know the policy making plan and public policy program, as well as the reasons for making a public decision;

2) Encouraging people's participation in the process of public policy making;

3) Improving people's active participation in public policy making and good management of Public Institutions;

4) Realizing transparent, effective, efficient, accountable, and responsible organization of the nation;

5) Learning the reasons behind public policies that influence many people's interests;

6) Developing knowledge and enrich the life of the nation; and/or improving information management and service within Public Institutions to provide high quality information service.

7) Code Of Profession is a regulation that concerns journalist profession in all editorial positions. In Indonesia, Law of the Republic of Indonesia Number: 40 of 1999 on Press, Article 1 Item 1 explains press as the following: "Press is a social institution and means of mass communication that performs journalistic activities, including seeking, acquiring, owning, storing, processing, and delivering information in the form of writing, sound, picture, sound and picture, data and graphics, as well as other functions by using print media, electronic media, and all kinds of available channels."

8) Code of Enterprise is a regulation that concerns the regulation of press companies. In Law of the Republic of Indonesia Number: 40 of 1999 on Press, the regulation for press companies are in Article 9 and 10, which state the following:

a) Each citizen of Indonesia and the nation has the right to establish a press company;

b) Each press company should be in a form of Indonesian legal entity. Press companies provide welfare to the journalists and press employees in the form of share ownership and or distribution of net profit and other forms of welfare.

c) Mass Media and Freedom of Information 
Freedom of the press is a concept that has been developing for quite a long time. According to Adji (2018), during the Old Order and New Order era, the meaning of free and responsible press put more emphasis on the power approach, leading to the large number of preventive policies towards press freedom and normative provisions that guaranteed press freedom, even though it still sparked implementative debates (Adji, 2008). Therefore, according to Adji (2018), there are several aspects of press freedom, namely:

1) Free Expression Press should be defined as freedom to own and state opinions through the press;

2) Preventive Censor as a legal entity is considered contradictory to the free press, hence should be banned;

3) The desired Freedom of Press, the desired concept, is not the kind that is limitless, unconditional, and not absolute;

4) Restriction: there is a possible restriction to be given to the press freedom, but the repressive kind;

5) The nature of Freedom of Press here is adjusted to the duties of press of not only being negative in its character and constructive in criticism, but also positive in character when delivering the government's initiatives.

\section{Crime Prevention Policy}

Crime prevention policy is a part of law enforcement process that aims to make people obey the law (Sunarso, 1981). People's obedience to the law is caused by the following three:

6) Fear of sin;

7) Fear of the imperative law applied by the authority;

8) Fear of shame of doing evil.

Law enforcement with the non-penal means targets and aims for the interests of internalization. Crime prevention policy according to Muladi (1995), is a policy or a rational attempt to prevent crime (Muladi, 1995). follows:

According to Soedarto (1981), criminal policy or crime prevention policy has three meanings as

1) In a narrow sense is all principles and methods that become the basis of reaction to violation of criminal law;

2) In a broad sense is all functions of law enforcers, including ways of working of the court and the police;

3) In the broadest sense is all policies applied through the legislation and official entities that aim to enforce central norms among the community.

Criminal policy or crime prevention policy as part of national development policy will encounter various interests. This is where people need to take concern of, that criminalization of an action as a crime or even the formulation of the penalties should never be intervened or embedded by certain interests that will eventually cause loss to the criminal law enforcement. The issue of criminalization itself according to Soedarto (1981), is as follows:

1) The use of criminal law should take the national development into account, of realizing just and prosperous community with equal material and spiritual values based on Pancasila. For that matter, the use of criminal law aims to prevent crime for the sake of public welfare and security;

2) Actions that are tried to be avoided and prevented by criminal law should be the undesirable actions, those who cause loss (material and spiritual) to the community;

3) The use of criminal law should also consider the cost benefit principle.

4) The use of criminal law should pay attention to the working capacity or capability of law enforcer entities and overblasting or overwork should be avoided.

\section{Crime Prevention without Punishment}

Along with the current development, crime prevention gets more identical to sentencing or penalty giving, which makes criminal law "scary". Debates over penalty as control over social behavior according to Packer in Prasetyo (1992), are social issues with considerable legal dimension.

Looking at the reasons proposed by Roeslan Saleh, penalties and criminal law are still considered necessary from the point of view criminal politics. Furthermore, to learn the value balance of the penalty results, it is necessary to pay attention to the value of justice, certainty, and usability of the penalty. Putting the emphasis on the rehabilitation form they may not be on target for the defendants, which refers to the value of usability, the author thinks that in the context of usability value, two sides are in operation; for people who face social issues and such issue is solved by sentencing for the defendant as 
perpetrator by still applying the usability value, concerns should be taken from the defendant's point of view as it is related to the defendant's human rights. Quoting Nawawi (2006) opinion, there are two central issues on criminal law enforcement, namely:

9) Which actions should be considered criminal act;

10) What sanctions should be used or imposed to the perpetrators.

Additionally, the use of criminal law as the means to prevent crime in Indonesia is not a separate issue; only, what should be taken into account is the policy line or the approach to use (Muladi and Nawawi, 2010).

\section{Mass Media Influencing the Public Perceptions}

The relatively soft and long-term influence of mass media on the behavior seems to be overlooked, while in fact it is related to the whole behavior of the community. This certainly is seen as a normal situation as the audience as consumers of information from the mass media have their own scheme consisting of faith, values, attitude, and preference of their own towards one instance or one ideology.

If the information in mass media does not make strong effect, it might mean that most audience, through the scheme they have, are ignorant about the information presented by the said mass media. A news reporting has positive impact when the following points proposed by Purnianti are present:

11) Regular reporting on crime news shows that each crime will be punished and serve as education for the community, that crime cannot be concealed and will be revealed eventually;

12) Crime news is often used as the material to pursue the perpetrators. Publication of the runaway murderer or kidnapper's photograph mostly helps the police catch the felon on the help of people who know them;

13) News reporting on the examination and trial mostly helps protect the perpetrators should there be misuse of authority by law enforcers.

With the development, television has different impacts than newspaper or print media in general due to some elements or forms of delivery that the print media do not have (Maulinni'am, 2017), namely:

1) Breaking News: refers to report of events that are occurring, to be developing, or shocking. Information is delivered with pressure on something urgent. The reports are supported by realtime videos, a set of pictures, and dramatic music. This also makes an appealing debate among media observers, the social and political field, that false information can easily spread. Meanwhile, it is not easy to correct such mistake with true information and audience will not simply change their minds as they already believe the false information. It is not guaranteed that the same audience will all see the correction at the time it is published.

2) Live Broadcast is a variety of perspective or reality that technology has become more sophisticated and it is highly possible to report news of fast occurring and unpredictable events in live. However, it does not mean that all events are worth live-reporting. The speed and ability to cover fast-developing events are only parts of several advantages of live broadcast.

Both breaking news and live broadcast are indeed an advantage for television compared to print media such as newspaper. However, in the context of crime reporting, its influence on the community, and its opinion on a criminal event, breaking news and live broadcast on television potentially have negative impacts on if the information lacks validity as both methods of reporting rely on speed. In fact, speedy information reporting is unlikely to be proportional to the accuracy of the information.

The forms of cooperation between law enforcers and mass media on the relationship of mass media, justice, and public opinion are as follows:

a) The fact about open criminal justice influences public opinion through mass media;

b) The consistently selective mass media reporting;

c) The courts learn from the mass media of how much the public knows;

d) The courts send feedback through the mass media and make an assumption on public opinion;

e) Mass media, also with certain assumption on public opinion, informs the audience on the process of the courts and presents the information based on the court's assumption on the public opinion;

f) The courts accept that assumption on public opinion based on mass media is the reflection of public's perspectives.

After looking at the relationship between mass media and the courts in general, it is also necessary that we look at the cooperation between mass media and each law enforcement institution in terms of the availability of each of them to give information on law enforcement. 


\section{Disparity in Criminal Sentencing}

The concept of equality before the law as one of the characteristics of the state of law also needs questioning as the reality shows that disparity actually occurs in law enforcement. Such fact is a manifestation of unequal treatment of justice to the same perpetrators of similar crime. For example, far different penalties are given in a case of rape with similar nature and characteristics. Muladi and Nawawi (2010), stated that:

"Defendants who, after comparing crimes, then feel they are victims of judicial caprice will become defendants who do not respect the law, whereas the appreciation for the law is one of the targets in the purpose of sentencing. This will show a serious problem as it will be an indicator and manifestation of the failure of a system to achieve equality in the State of Law while at the same time weaken people's trust in the system of criminal law administration. Something to not expect if the disparity is not overcome is the rise of demoralization and anti-rehabilitation attitudes among defendants with more severe penalties than others in comparable cases".

Criminal disparity comes from the different sentencing to similar criminal acts. This sentencing is certainly the penalty given by the judges to the perpetrators of crime, thus it can be said the figure of judge in the disparity is highly determinant. According to Harkrisnowo (2003), criminal disparity may occur in several categories, namely:

1) Disparity in similar crimes

2) Disparity in crimes with similar level of severity;

3) Disparity in the penalty given by one panel of judges.

Disparity in the penalty given by different panels of judges for the same crime. In the historical perspective, disparity develops and becomes part of law enforcement in Indonesia. Disparity does not only occur in the same crime, but also on the same level of severity and the judges, both from one same panel or different panels for the same crime. The reality regarding the scope of the growth of disparity certainly creates inconsistency in the judicial environment.

Some factors influence criminal disparity, one of them is from the loosely formulated law itself. In the positive law of Indonesia, judges have great freedom to pick the type of sentencing (straafsoort) of their desire in connection with the use of alternative system in the sentencing threat in the Laws. Example of alternative system can be seen from the provisions of article 188 of Criminal Code (KUHP), which reads:

Whoever due to an error (negligence) causes fire, explosion or flood, is threatened with imprisonment for a maximum of five years or a maximum of one year imprisonment or a fine of at most four thousand five hundred Rupiah, if such action arises a general danger to the goods, if such action arises a danger to the life of another person, or if such action causes the person to die.

The formulation of sanctions in corruption crime that potentially carries disparity is, one of them, mentioned in the provisions of Article 2 paragraph (1) of Law Number: 31 of 1999 on Corruption Eradication, which stipulates:

Anyone who unlawfully enriches oneself or another person or a corporation that can harm the state finances or the economy of the country, is punished with imprisonment for life or imprisonment for a minimum of 4 (four) years and a maximum of 20 (twenty) year and a fine of at least Rp200,000,000 (two hundred million Rupiah) and a maximum of Rp1,000,000,000 (one billion Rupiah).

In KUHP, there are minimum criminal sanctions and maximum criminal sanctions. Minimum criminal sanctions are regulated in Article 12 paragraph (2) of KUHP: "Prison sentence is a minimum of one day and a maximum of fifteen years in a row", while maximum criminal sanctions are regulated in Article 12 paragraph (2) of KUHP: Prison sentences for a certain period of time should not be more than twenty years." There is also life imprisonment sanction regulated in Article 12 paragraph (3) of KUHP:

Prison sentences for a certain period of time may be imposed for twenty consecutive years, in which for the sentence the judge may choose between death sentence, life sentence and imprisonment for a certain period of time or between imprisonment for a certain period of time; the fifteen-year limit may also be surpassed because of conclusions (concursus), repetitions (recidivists) or because of those specified in Articles 52 and 52a.

The negative impacts of criminal disparity according to Kennedy (1976), as quoted by Nawawi (2006) are:

1) Growth or development of cynical feelings towards the existing criminal system;

2) Failure to prevent a crime;

3) Encouraging crime;

4) Obstructing the correctional actions to the offenders. 
A legal fact can be seen from various points of view. In this case, there are legal experts who do not think that disparity only brings negative impacts and therefore should be reduced. They do not see criminal disparity as an error or a defect in Indonesian criminal law enforcement. In connection with this matter, Adji (1984), argued that criminal disparity can be justified in the following terms:

1. Criminal disparity can be justified against penalties of rather heavy offenses, but such disparity must be accompanied by clear reasons for justification;

2. Criminal disparity can be justified if it is reasonable.

Mahfud (2007), stated that Indonesia is destroyed by corruption, corruption flourishes because of the corrupt courts, and the courts are difficult to clean without extraordinary methods. It is inevitable now that many law enforcement institutions in the regions have made instruction to hunt down corruptors as ATMs or effective new money withdrawal tools. Many of the law enforcement institutions then extort regional officials by threatening to run the legal process on alleged corruption. Several factors causing corruption in Indonesia include:

1) The widespread practice of corruption is caused by ignorance towards the existence of a conflict of interest. There is no strict separation between executive and judicial institutions, especially in terms of the appointment of judicial officials. In a certain sense, the president's prerogative right in the appointment of prosecutors is the accumulation of power and which has implications for conflict of interests;

2) Power concentration and ineffective control. This concentration of power is very strong at the peak level of the power hierarchy;

3) Decision making which is apparently not only carried out by authorized officials. In fact, many decisions are the results of negotiation procedures with parties related to the socioeconomic field; and

4) The need for political parties to fund elections.

The rule of law is no other than crystallization of competing political desires. In fact, it is clear that politics plays a great role in determining for the workings of the law. Rahardjo (2008), stated that if we see the relationship among law subsystems, it can be seen that politics has greater concentration of energy, which causes the law to always be in the weaker position. Additionally, law is a manifestation of public policies influenced by political issues, and such political changes highly affect the attitude of public policy, and law is a product of politics that perceives itself as formalization or crystallization of competing and interacting political desires.

According to Harkrisnowo (2003), criminal disparity can occur in several categories, namely:

1) Disparity in the same crime;

2) Disparity in crimes with equal level of severity;

3) Disparity in decisions made by the same panel of judges;

4) Disparity in decisions made by different panels of judges for the same criminal act.

In order to make efforts to reduce criminal disparity, a guide on sentencing is regulated in the Bill of Criminal Law Book I of 2012 in Article 55 and Article 56 as follows:

Article 55

(1) In sentencing, the following must be considered:

(a) Errors of the perpetrators;

(b) Motives and purposes of committing the crime;

(c) Inner attitude of the perpetrators;

(d) Whether the crime was planned or unplanned;

(e) How the crime is committed;

(f) Attitude and behavior of the perpetrators after committing the crime;

(g) History of life, social conditions, and economic condition of the perpetrators;

(h) Effect of crimes on the future of the perpetrators;

(i) Effect of crimes on the victims or family of the victims;

(j) Forgiveness from victims and/or their families; and or

(k) The public's view of the crime committed

(l) The lightness of the crimes, personal circumstances of the perpetrators or the circumstances at which an act is carried out or which occurs later can be taken into consideration not to impose criminal sanctions or to take action by considering aspects of humanity and justice.

Article 56 
"A person who commits a crime is not exempted from criminal liability based on the reason of elimination of sentencing, if the person has intentionally caused a situation which could be the reason for the removal of the sentencing".

Furthermore, regarding the sentencing guidelines, it is also necessary to know the sentencing is oriented towards the "people" (perpetrators of crime) factor, thus the idea of "individualization of sentencing" also takes role in the general rules of sentencing as mentioned in Book I of Bill of Criminal Code. The idea or rationale of "individualization of sentencing" is seen, among others, in the general rules of the Bill as follows:

a. As stated above, the Bill has asserted in Article 37 that "there is no sentencing without errors" is a highly fundamental principle;

b. In the provisions of reasons of eliminating penalty, especially in the forgiveness reason, issues of error, force, out-of-limit forced defence, inability to take responsibility, and children under 12 years old are included;

c. In the "sentencing guidelines" (Article 52), judges are obliged to consider some factors: motives, inner attitude and errors of the perpetrators, the era of the perpetrators, their life history and social-economic justice, as well as how the crime affects the future of the perpetrators;

d. In the guide of "forgiveness/remission", the judges (see quoted Article 52 paragraph (2) above) also consider the factor of personal circumstances of the perpetrators and humanitarian considerations;

e. In the provisions on "reducing and increasing the sentence" (Article 132, 133, and 134) some factors are considered:

1. Whether the defendant voluntarily surrenders to the authorities;

2. Whether the defendant voluntarily compensates or repairs the damage caused;

3. Whether there is an extreme mental shock;

4. Whether the defendant is a newly pregnant woman;

5. Whether there is inability to take responsibility;

6. Whether the defendant is a civil servant who violates their position/misuses their authority;

7. Whether the defendant misuses their skill/profession;

8. Whether the defendant is a recidivist.

Senator Kennedy (1976) stated that with the absence of guidelines in criminal law, diversity of sentencing will occur even though the judges will perform their duties very responsibly and meticulously.

What Kennedy (1976) means by sentencing benchmark is the average sentence imposed by the judges in certain court regions such as High Court of Jakarta's region. Therefore, extreme, too severe, or too light penalties can be limited. Such benchmark is not absolute. Each panel of judges is free to deviate from the benchmark as long as they provide sufficient considerations in their decisions.

In order to overcome striking disparity, Eddy Djunaedi Karnasudirdja elaborated some techniques to reduce or minimize disparity in the judges' decisions, among others:

1) By using data of sentencing;

2) By using "Checking List" or "table of sentencing";

3) By using "prediction table" or "forecasting table"; or

4) By using "sentencing benchmark".

Disparity in sentencing can be caused by the law itself and the use of freedom of judges, which, despite being recognized by the laws and is actually needed to guarantee justice, often crosses the limit, leading to reduced legal authority in Indonesia. This problem of criminal disparity growing within the law enforcement certainly gives rise to inevitable effects.

Related to this matter, the formulation of corruption crime as set in the laws is regulated in a way that minimizes disparity in the judges' decisions. The formulation is mainly connected to the following provisions: a. Philosophy of Sentencing

The philosophy of sentencing, which has not been clearly regulated in the PTPK laws and KUHP, has external influences in the form of varied philosophies of sentencing embraced by the judges, and this could potentially cause disparity in their decisions. Conservative (classic) judges with a sentencing philosophy that sees criminal law as "a revenge or public grudge or giving of sorrow", will tend to impose heavy penalty to the defendant. Conversely, progressive (modern) judges who see criminal law as "coaching or protection" will tend to impose light penalty to the defendant; 


\section{Sentencing Guidelines}

Based on the fact we see in the law enforcement on a daily basis, disparity grows and becomes a culture in the Indonesian law enforcement. Disparity does not only occur in the same crime, but also in the severity of the crime and from the judge's decision, both from the same panel of judges and different panels of judges for the same crime. The fact about the growth scope of the disparity certainly creates inconsistency in the judicial system. The factor that may cause criminal disparity is the lack of sentencing guidelines for the judges.

\section{Sentencing Benchmark}

What it means by sentencing benchmark is the average sentence imposed by the judges in certain court regions, such as the High Court of Central Jakarta. Therefore, extreme, too severe, or too light penalties can be limited. Such benchmark is not absolute. Each panel of judges is free to deviate from the benchmark as long as they provide sufficient considerations in their decisions. Without sentencing guidelines, judges will not have the guide of the severity of the sentence, which certainly will give room for disparity to develop in the judge's decision.

\section{Internal Factors Originating from the Judge}

Regarding the factors originating from the judges, especially those related to professionalism and integrity, to put concerns on the case at hand, given the goal of sentencing to achieve, different sentences will be given to the same crime. (2006), are:

The results of this striking criminal disparity, according to Kennedy (1976), as quoted by Nawawi

1) Growth or development of cynical feelings towards the existing criminal system;

2) Failure to prevent a crime;

3) Encouraging crime;

4) Obstructing the correctional actions to the offenders.

From Kennedy (1976)'s opinion, we learn that the impacts of criminal disparity are not in line with the goals of criminal law and the spirit of the philosophy of sentencing. Criminal disparity is increasingly causing chaos in the community. Not only it is hurting the sense of justice, but it also encourages people to commit crime. This condition eventually leads to failure of criminal law enforcement, where the community views law enforcement as something trivial.

In connection with this matter, Adji (2008), argued that criminal disparity can be justified in the following terms:

i. Criminal disparity can be justified against penalties of rather heavy offenses, but such disparity must be accompanied by clear reasons for justification

ii. Criminal disparity can be justified if it is reasonable.

iii. Problems regarding criminal disparity in law enforcement in Indonesia cannot simply be eliminated. What can be done is only efforts to minimize criminal disparities occuring in the community. Based on the views of various scholars, connected with the sentencing philosophy and the purpose of law itself, the solution can be found in Muladi's view that the most important attempt to make in facing the criminal disparity problem is judge's appreciation to the principle of proportionality between the interests of the community, the interests of the State, the interests of the perpetrators of the crime and the interests of victims of crime.

iv. In connection with this, Suringa and Remmelink (1996), concluded that the sentencing will not and will never give satisfying solution as it is difficult to possibly have a fixed line for that. Therefore, it is impossible to eliminate criminal disparity to null. What needs to be attempted is proper and suitable sentencing (consistency of sentence). In this respect, the sentencing is not aimed to reach uniformity or absolute union as it is contradictory with the judge's freedom, the maximum and minimum limit of sentencing, and the sense of justice and faith of the judge. During such situation, for a solution, he quoted Oimen by stating that the point is not to give the same sentence, but to try by using Robert Kennedy (1976)'s words "Not making sentence equal, but in making sentencing philosiophies agree".

\section{CONCLUSION}

a. Mass media has an important role in the efforts of corruption eradication, especially the disparity in the judges' decisions as included in "Nine Elements of Journalism" that the first obligation of journalism is truth. The truth here does not only refer to the fair, balanced, accurate, and 
disciplined verification of the seeking, but also about commitment to the citizen, namely the obligation to always be free from all obligation except for loyalty to the public interests. This obligation is the social surveillance function in the form of information distribution and objective interpretation on various events occurring inside and outside the social circle for social control purposes in order to prevent undesired occurrences, such as disparity in the judges' decisions in corruption crime cases.

b. Mass media in the 4.0 industry should make innovation and have critical soul in perceiving a decision. The mass media is still working in the scope of education to the community to be more careful in understanding the in-depth situation and socializing the meaning of disparity, how it happens, and how to prevent and eradicate it. Such knowledge is needed in order to have the next generation minimize disparity in the judges' corruption case decision and in order for the Indonesian people to have better insights.

c. Partnership between mass media and law enforcers may help develop cooperation among law enforcement institutions. Since competition in the prevention of crime among them still exists, the role of mass media is recovering the image and people's trust in enforcement institutions. The efforts of strengthening mass media's role in crime prevention policy is not limited to social control over law enforcement, but also how mass media can run the preventive function. However, in control function, the interests of human rights involved in a criminal case, for example, should also be of concern. Hence, mass media should put public interest for their curiosity about information as well as the interest of human rights for proportional news reporting first in order to prevent them from judging an event or assassination of the characters involved. This way, they instead can work on their preventive function, legal learning, legal awareness, legal obedience, and giving deterrent effect to the offenders.

\section{Conflict of Interest Disclosure Form}

This study was self-funded and does not contain any studies with human participants performed by any of the authors.

We hereby confirm that the manuscript has no any actual or potential conflict of interest with any parties, including any financial, personal or other relationships with other people or organizations within three years of beginning the submitted work that could inappropriately influence or be perceived to influence.

All procedures performed in studies involving human participants were in accordance with the ethical standards of the institutional.

\section{REFERENCE}

Soetandyo, W. (2002). Hukum, Paradigma, Metode dan Dinamika Masalahnya. Jakarta: Huma.

Rahardjo, S. (2008). Membedah Hukum Progresif. Penerbit Buku Kompas.

Reksodiputro, M. (2010). Komisi Yudisial: Wewenang dalam Rangka Menegakkan Kehormatan dan Keluhuran Martabat serta menjaga Perilaku Hakim di Indonesia. Bunga Rampai Setahun Komisi Yudisial.

Soekanto, S., \& Mamudji, S. (1986). Penelitian Hukum. Universitas Indonesia Pers.

Manan, B. (1999). Penelitian di Bidang Hukum. Jurnal Hukum Puslitbangkum.

Dja'far, A. (1991). Jurnalistik Masa Kini. Ghalia Indonesia.

McQuail, D. (Ed.). (2002). McQuail's reader in mass communication theory. Sage.

Effendy, O. U. (1989). Kamus komunikasi. Mandar Maju.

Syah, S. (2011). Rambu-rambu jurnalistik: dari undang-undang hingga hati nurani. Pustaka Pelajar.

Puntoadi, D. (2011). Menciptakan Penjualan via Social Media. Elex Media Komputindo.

Juditha, C. (2018). Hoax Communication Interactivity in Social Media and Anticipation (Interaksi Komunikasi Hoax di Media Sosial serta Antisipasinya). Pekommas, 3(1).

Entman, R. M. (1989). How the media affect what people think: An information processing approach. The journal of Politics, 51(2), 347-370.

Arrigo, B. A. (2006). Criminal behavior: A systems approach. Prentice Hall.

Wiryawan, H. (2007). Dasar-Dasar Hukum Media. Pustaka Pelajar.

Sunarso, S. (2004). Penegakan Hukum Psikotropika: dalam Kajian Sosiologi Hukum. PT. Raja Grafindo Persada.

Muladi. (1995). Kapita selekta sistem peradilan pidana. Badan Penerbit Universitas Diponegoro.

Soedarto. (1981). Kapita selekta hukum pidana. Alumni. 
Prasetyo, T. Pidana Dalam Hukum Islam Dan Perbandingan Dengan Hukum Pidana Nasioual.

Kennedy, E. M. (1976). Criminal sentencing: A game of chance. Judicature, 60, 208.

Remmelink, J., \& Hazewinkel-Suringa, D. (1996). Mr. D. Hazewinkel-Suringa's Inleiding tot de studie van het Nederlandse strafrecht. Kluwer.

Arief, B. N. (2006). Tindak pidana mayantara: perkembangan kajian cyber crime di Indonesia. RajaGrafindo Persada. 